\section{Prevention of measles: vaccine efficacy and potential effectiveness of a vaccination programme on entry to school}

A measles outbreak in a primary school was investigated to measure vaccine efficacy, examine whether medical records on entry to school predicted subsequent illness with measles, record lost schooldays for each child with measles, and see if the outbreak could be terminated by offering vaccination to any remaining susceptible children.

\section{Subjects, methods, and results}

As all cases of measles in the outbreak were in children aged under 8 only the 136 children aged between 3 and 8 in seven open plan infant and nursery classes were considered to be at risk. Vaccination state is most accurately recorded on the infant vaccination record, which for many children had been transferred to their school medical record. Questionnaires, inquiring about illness with and vaccination against measles, were distributed to parents of 124 children present at school on one day, and 84 replied within 48 hours. The infant vaccination records for four children in whom the vaccine was reported to have failed before 1985 were not present in their school medical records, so local clinics and general practitioners were contacted to establish their true vaccination state.

During the outbreak there were 35 cases of measles, which were either diagnosed by a general practitioner or defined as rash for three or more days and fever with cough or coryza or conjunctivitis. All cases were in unvaccinated children, thus the observed efficacy of measles vaccine was $100 \%$ (table). In the measurement of vaccine efficacy reported illness with measles before 1985 in four vaccinated and nine unvaccinated children was ignored '; examination of clinic and practice records for these four vaccinated children confirmed that only one child had developed measles, diagnosed by a doctor, when aged 51 months after vaccination at 23 months.

On entry to school, history of illness with or vaccination against measles, or both, had been noted in many school medical records, and this information together with the infant vaccination record, if contained in the school medical record, was used to assess each child's probable immune state to measles at the

Efficacy of measles vaccine during outbreak in primary school ${ }^{\star}$

\begin{tabular}{lcc}
\hline $\begin{array}{c}\text { Vaccine state before 1985 } \\
\text { outbreakt }\end{array}$ & $\begin{array}{c}\text { No of children ill during } \\
\text { outbreak }\end{array}$ & $\begin{array}{c}\text { No of children not ill during } \\
\text { outbreak }\end{array}$ \\
\hline Vaccinated $(n=51)$ & 35 & 51 \\
Not vaccinated $(n=58)$ & 23 \\
\hline
\end{tabular}

^Excludes 27 children whose vaccine state was unknown, none of whom had measles.

†From parents' questionnaire or infant vaccination record, or both.

time of their medical examination on entry to school. Forty two children were classified as probably susceptible, 73 as immune ( 42 after vaccination and 31 after illness with measles), and 21 as immune state unknown. The subsequent number of cases of measles in those susceptible was $35(83 \%)$, including nine cases at school before the 1985 outbreak; in those who had been vaccinated two $(5 \%)$; in those who had measles before school entry two $(6 \%)$; and in the immune state unknown group five $(24 \%)$. For a few children the later information obtained from the questionnaire changed the assessment of vaccine state at the time of the outbreak.

Each child with measles was absent for an average of eight schooldays. Seven weeks after the first case had occurred only five children were identified as possibly still susceptible. They were offered immediate vaccination; two did not respond, one who had previously been advised against measles vaccination refused again, one accepted the vaccine, and the other was found to have been vaccinated before beginning school. During the rest of the term there were no further cases of measles.

\section{Comment}

From 1980 to 1983 over 37000 cases of measles were notified yearly in England and Wales in children aged 5-9 years. ${ }^{2}$ This age group accounts for $38 \%$ of all notifications of measles, and transmission of measles increases three times each year, when school terms begin. ${ }^{3}$ Many districts are responding to the 1984 measles control initiative ${ }^{4}$ by offering measles vaccination at school entry.

Our investigation showed the efficacy of measles vaccine in a primary school and that most of the high morbidity from measles might have been avoided if the susceptible children, most of them readily identifiable, had been vaccinated at school entry. To be successful a vaccination programme to control an outbreak of measles in a school should be implemented within 10 days of onset of the primary case..$^{5}$
We thank the school nurse, Mrs Romano, and headmistress, Mrs Toal, for their help. Dr Fernandes undertook this study while on a short attachment from Milton Keynes Health Authority.

1 Orenstein WA, Bernier RH, Dondero TJ, et al. Field evaluation of vaccine efficacy. Weekly Epidemiological Record 1985;60:133-6.

2 Office of Population Censuses and Surveys. Communicable disease statistics, England and Wales. London: HMSO, 1980-3. (Series MB2 No 7-10.)

3 Fine PEM, Clarkson JA. Measles in England and Wales 1: an analysis of factors underlying seasonal trends. Int $f$ Epidemiol 1982;11:5-14.

4 Department of Health and Social Security. Measles immunisation. London: DHSS, 1984 $(\mathrm{HN}(84) 19$.)

5 Ruuskanen O, Salmi TT, Halonen P. Measles vaccination after exposure to natural measles. $\mathscr{f}$ Pediatrics 1978;93:43-6.

(Accepted 12 September 1985)

Public Health Laboratory Service Communicable Disease Surveillance Centre, London NW9 5EQ

VASCO FERNANDES, MRCGP, MFCM, specialist in community medicine

O N GILL, MB, MFCM, consultant epidemiologist (also at North East Thames Regional Health Authority)

Correspondence to: Dr Gill.

\section{$C$ reactive protein concentration as screening test for bacterial infection in febrile children}

Interest has focused on $\mathrm{C}$ reactive protein concentrations ${ }^{1}$ as an early predictor of bacterial sepsis in children. ${ }^{2-4}$ We compared a semiquantitative assay of $\mathrm{C}$ reactive protein with total and differential white cell counts in the early diagnosis of childhood infection.

\section{Patients, methods, and results}

All children admitted with fever (temperature $>37 \cdot 5^{\circ} \mathrm{C}$ ) to the paediatric medical unit from 1 October 1983 to 31 July 1984 were studied. After history taking and a full physical examination, blood was taken for full and differential white cell counts and for measuring $C$ reactive protein concentrations. Other relevant serological, haematological, and bacteriological tests were performed as dictated by the history and presenting signs. Urine culture was performed in all children. Bacterial infection was diagnosed by culture of pathogenic bacteria from appropriate specimens - for example, three consecutive urine specimens or suprapubic aspirate. Appreciable consolidation on chest $x$ ray films, particularly with lobar distribution, was also considered diagnostic.

Total and differential white cell counts were performed by standard laboratory techniques, a count of $\geqslant 10 \times 10^{9} / 1$ with $\geqslant 60 \%$ neutrophils being regarded as indicating bacterial infection. Assay of $C$ reactive protein concentrations was performed on $250 \mu \mathrm{l}$ of serum using ICL scientific rapid latex agglutination slide test in serial dilutions to give a positive result at a $\mathrm{C}$ reactive protein concentration $\geqslant 15 \mathrm{mg} / \mathrm{l}$. Statistical analysis was by $\chi^{2}$ test.

Of the 430 febrile children admitted, 129 were excluded from analysis, because of previous antibiotic treatment in 79 and acute otitis media (unconfirmed bacteriologically) in 50 . The remaining 301 children were aged from 1 week to 14 years (median $1 \cdot 25$ years). Children under 2 , who have the greatest risk of serious bacterial infection, were analysed separately.

The table shows the results of assay with $\mathrm{C}$ reactive protein concentrations compared with the results of white cell count for both infected and non-infected children, with their respective specificities and sensitivities. Hence a raised C reactive protein concentration at admission accurately predicted bacterial

Comparison of diagnostic accuracy (No (\%) of children) of assay of $C$ reactive protein concentrations and white cell count in febrile children

\begin{tabular}{lcc}
\hline & $\begin{array}{c}\text { C reactive protein } \\
\text { concentrations }\end{array}$ & White cell count \\
\hline & $\geqslant 15 \mathrm{mg} / \mathrm{l}$ & $\begin{array}{c}\geqslant 10 \times 10^{9} / \mathrm{l} \\
\text { Children with bacterial infection: }\end{array}$ \\
$\begin{array}{l}\text { All ages }(\mathrm{n}=121) \\
<2 \text { years }(\mathrm{n}=75)\end{array}$ & $58(48)$ & $57(47)$ \\
& $32(43)$ & $29(39)$ \\
& $<15 \mathrm{mg} / \mathrm{l}$ & $<10 \times 10^{9} / \mathrm{l}$ \\
Children with non-bacterial & & $<60 \%$ polymorphs \\
infection: & $173(96)$ & $126(70)$ \\
All ages $(\mathrm{n}=180)$ & $112(99)$ & $87(77)$ \\
$<2$ years $(\mathrm{n}=113)$ & &
\end{tabular}

